\title{
Articles
}

\author{
Zhanna Kormina, Sergey Shtyrkov
}

\section{The Female Spiritual Elder and Death: Some Thoughts on Contemporary Lives of Russian Orthodox Saints}

\author{
Translation by Jan Surer
}

DOI: $10.22394 / 2311-3448-2017-4-2-4-24$

Jeanne Kormina - Assistant Professor at the Higher School of Economics (St. Petersburg, Russia). kormina@eu.spb.ru

Sergey Shtyrkov - Senior Researcher at the Museum of Anthropology and Ethnography of the Russian Academy of Sciences (Kunstkamera); Assistant Professor at the European University at St. Petersburg (Russia).shtyr@eu.spb.ru

In contemporary Orthodox hagiography a special type of saint has emerged - blessed female spiritual elders (blazhennye staritsy). In some respects this form of sainthood is a successor to the traditional "fools for the sake of Christ." Yet the staritsy have their distinctive features, chief among them the saint's possession of an incurable disease such as blindness or motor function disorders. The meaning of these ailments can be interpreted as a sign of permanent liminality and the person's divine election. The disorder indicates that while alive the female elder also belongs to the world of the dead (or the next world). The creation of these iconic narratives can be seen as an attempt to democratize the hagiographical canon by including folk religious motifs and images. This "folklorization" of the genre of church hagiography expresses the idea that the Orthodox faith has deep roots in popular religiosity and therefore can be accessible to common people.

Keywords: anthropology of religion, Orthodox saints, contemporary hagiography, female sainthood, body, death. 


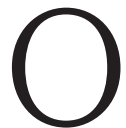

$\mathrm{N}$ a spring day in 1952, sixty-seven-year-old Muscovite Matrona Nikonova sensed the approach of death and called for a priest. During confession "she was very agitated," and when the priest asked, "Are you really afraid of death?" she answered, "I'm afraid" (Matronushka 2009, 56). This short little dialogue, when included in an official version of the life of the blessed female elder Matrona, is always accompanied by the publishers' explanatory commentary - for example, that the priest was very surprised by such an answer, or that she feared death just as ordinary, sinful people do, "out of her humility," that is, that she thereby continued to perform special Christian spiritual feats even on her deathbed. A paradox, subtle but comprehensible to a devout reader, shapes these commentaries apparently, there are saints who fear death. However minimal the devout reader's acquaintance with the hagiographical tradition, he or she knows, of course, that for those special individuals whom others consider saints the fear of death is not typical. Saints have a distinctive, trustful relationship with death: they know a lot about it, they expect it, they foresee it and in many cases experience joyous excitement because of the coming encounter with it. For them, as for the Apostle Paul, "to die is gain" (Philippians 1:21, ESV).

Even in a strict legal sense saints become saints only after, or, more precisely, as a result of their death. Until a hero of the faith has crossed from this life to eternal life, no icons or akathists of the saint exist, regardless of the devout sentiments the saint may evoke in his or her most ardent devotees. Consider a typical hagiological claim, that so-and-so was a saint even while still living. One cannot fail to notice the oxymoronic meaning of this formulation, which contains an unspoken presumption: one speaks of a living righteous person, "N," as if the person were a saint, knowing that this status can be achieved only after death, that is, we get ahead of ourselves, conferring on "N" this honorific title in advance. A similar play on meanings is contained in a phrase with the opposite sense and the corresponding practice of conferring the title of hero (of a certain state) posthumously. A hero decides to perform a great deed and carries out the intended act while still living. Officially, however, the person becomes a hero after death, that is, retroactively. A saint, too, is a saint though still alive. It is as if the saint were betrothed to sainthood, and one must only wait for the moment when one can legally formalize the actual state of affairs. Then, too, the demise of the future saint is a signal for the saint's devotees to collect the materials - documents and narratives - that will be used for the person's glorification among the saints. It is precisely at this moment that the saint's images change their status - portraits become icons. 
In those Christian traditions in which the veneration of saints has acquired settled forms, death and sainthood are inextricably linked, genetically and functionally. One of the first specifically Christian customs was the practice of venerating the remains of martyrs who had borne witness with their lives, or, more accurately, their deaths, to their fidelity to Jesus Christ - their faith in his redemptive sacrifice and resurrection. As is well known, a special relationship to particular people who have died appeared prior to, as well as within, Christianity. But the early Christians' custom of gathering at the tombs of their first saints for special feast days truly scandalized their neighbors of other faiths. Peter Brown, the distinguished scholar of the cult of the saints, illustrates the sense of revulsion a person of antiquity felt toward the bodies of the dead and the rejection of Christian ritual acts through the words of the Roman emperor Julian the Apostate, addressed to Christians: "You have filled the whole world with tombs and sepulchres" (Brown 1981, 7). Mingled with the aesthetic grounds for the rejection of Christian customs, there was certainly also their contemporaries' incomprehension of how the veneration of someone else's dead, of someone who was not one's relative, was able to shape the religious life of so many people. The spiritual families forming around the tombs of new saints were an indisputable affront to the basic dominant ideas of the ancient world's social imagination.

The cult of the saints, the veneration of their deaths and relics, has a long, colorful history and to this day remains a testament to true piety to some, and a bizarre, almost pagan superstition to others. And although one can speak with confidence of the continuance of practices dating to the first centuries of church history, ${ }^{1}$ to ignore the significant changes that have occurred over the intervening centuries would be idealistic at the very least. Each era and culture expects and produces its own "very special dead" (Brown 1981, 69) and its own views on death and establishes varied, and sometimes unexpected, relations between the former and the latter. But our goal is not the construction of a complete picture of this phenomenon at the level of universal church history. A comparatively peripheral question interests us: how the phenomena of sainthood and death are associated in the hagiological imagination of Orthodox believers as they reflect on the historical path of their church in the twentieth century - more precisely,

1. See the description of the "typical" model for establishing the veneration of a saint in Cunningham 2005. 
the "short twentieth century," delimited chronologically by the dates of the birth and death of the Soviet state. ${ }^{2}$

\section{The New Wine of Contemporary Hagiography}

Looking back and trying to evaluate the hagiographical inheritance left to the Russian Orthodox Church by the Soviet period in the Church's life,$^{3}$ one can somewhat conventionally distinguish two separate groups of saints, each of which occupies its own clearly defined place in the space of Orthodox piety. The first group is that of the New Martyrs, officially designated the "New Martyrs and Confessors of the Russian Land." In contrast to martyrs in the narrow sense, those who perished for their faith at the hands of the persecutors of Christianity in the first centuries of its existence, the New Martyrs (understood as a separate hagiological type) suffered in modern or contemporary times. In both instances, the persecutors were those who implemented the official policy of the state - the pagan state during the Roman Empire, the Islamic state in Ottoman Turkey, the atheistic, communist regimes of the twentieth century. Moreover, the images of the New Martyrs and the initiatives to canonize them often had "national-patriotic" overtones, that is, they were directly linked with attempts by one national autocephalous church or another to articulate the specific characteristics of its own historical path and mission.

The canonization of New Martyrs in the Russian Orthodox Church, Moscow Patriarchate (ROC MP), has become a large-scale phenomenon over the last decade and a half, and those saints glorified for veneration by the entire Church or a locality now number more than 1,500 . The second group of saints, which will constitute our main topic, is definitely less numerous than the first group. This second group consists of the "blessed female elders," representatives of a specific type of sainthood that began to develop in the second half of the nineteenth centu-

2. Of course, we realize these dates are entirely a matter of convention. Clearly, the turning point in social consciousness marked by the date of 1917 had its roots in events and social processes that occurred much earlier, and, indeed, the conclusion of the Soviet era would be better dated not to 1991 but perhaps to 1988. One sees glimpses of the regime negating its very self - or, at any rate, doubting its own legitimacy - in its permission of the public celebration of the millennium of the baptism of Rus', canonizations, and the idealization of prerevolutionary Russia. Contrasted with the exhaustion of fundamental Soviet ideologies, discursive clichés, and portraits of heroes, the images of prerevolutionary Russia seemed appealing and authentic even then (recall, for example, the 1992 film The Russia We Lost).

3. For a study of the history of the canonization of saints in Russian Orthodoxy in the twentieth century, see Semenenko-Basin 2010. 
ry as a separate hagiographical phenomenon and object of Orthodox piety and flourished by the beginning of the present century. The image of St. Matrona of Moscow serves as this latter group's ideal exemplar.

We base our reflections on death and sainthood in the twentieth century mainly on the reading of a special genre of literature, the lives of the saints. This literature, despite its apparent uniformity, is in fact quite varied and diverse. For example, multivolume compendia of saints' lives exist, menologies (Chet'i minei [literally "monthly readings" - Translator]) in which the stories of saints' great deeds and miracles are collected, beginning with the early Christian martyrs. These are entirely "official" documents housed in the libraries of religious seminaries and the great cathedrals and may be used in liturgical practice. Another form of official hagiographical text consists of the materials from the work of the canonization commissions, which serve as the basis of the documents for the church councils that decide on the canonization of new saints. But, in addition, there are numerous slim booklets one may obtain at low cost in church shops, as well as in entirely secular bookstores. These books are often written in simple language, intended for a mass readership, and contain information and concepts that from a canonical perspective are open to question, to say the least. Within the body of sources concerning saints' lives one must also include such contemporary conduits of hagiographical information as documentary films and television programs.

Although one usually thinks of the lives of the saints as fixed texts in which the image of a saint has reached a static form, ongoing hagiographical creation is a necessary condition for a saint's veneration, even for a saint who died and was glorified long ago. When a saint is still beloved by his or her devotees and is consequently important in contemporary religious life, the saint's new posthumous miracles will be included in publications of "old" lives. Furthermore, the dynamism of hagiography as a religious-artistic process manifests itself in the possibility of reinterpreting already well-known elements of the saint's life narrative, and consequently nuances that hitherto had not been brought out appear in the saint's literary portrait. In this way, change in a hagiography on the level of both narrative and interpretation defines the forms of veneration of the saints, that is, the reasons for which the faithful resort to the saints' intercession, the methods of communicating with the saints and their representatives in this world, and the like. ${ }^{4}$ In other words, the hagiological portrait of a saint

4. One may read of the functioning of institutionalized mechanisms of mediation between the widely venerated saint Ksenia the Blessed and her devotees in Kormina and Shtyrkov 2008. 
is contingent upon the present-day needs of the faithful, "each day's own trouble." But besides this, what will be written about a particular Christian ascetic depends on the information about him or her that lies at the disposal of the hagiographer, that is, of that person who set out to create a new literary icon or to update one already in existence.

Clearly, hagiography on the one hand, and the practice of venerating a saint on the other, exist in a complex relationship of both functional and logical interdependence. For example, the Orthodox practice of canonization presupposes the following logic: in order to be glorified by the Church, a saint must already be an object of pious veneration for which there must be evidence. Therefore, it is precisely the practice of invoking a still living or already deceased hero of the faith that leads to the appearance of those testimonies of miracles that will be reflected in the saint's hagiography or in materials for the compilation of that hagiography presented to the special commissions on canonization. And it is specifically this evidence that will advance the saint's canonization. But sometimes it is possible to assert confidently that hagiographical writings not only reflect the established cult of a saint but also actively participate in the cult's development, popularizing and even initiating it and transforming it from a localized to a church-wide cult.

This was exactly the case with respect to the "spiritual career" of Matrona of Moscow: in 1993 the printing house of the Moscow-area Novo-Golutvin Monastery published a "proto-saint's life" concerning her. It consisted of the collected reminiscences of several people who had known her. At the end of the 1990 s the future saint came to the attention of influential Church figures, and in 1998 her remains were transferred from the Danilovsky cemetery to the then-restored Pokrovsky women's monastery. Subsequently her canonization was carried out, and on the basis of the above mentioned reminiscences, which were brought into line with the requirements of hagiographical literary etiquette and hagiological norms, her "official" saint's life was written. (For more detail, see Kormina 2010.)

Not only may one harness administrative resources toward the glorification of a saint, as occurred in the case of St. Matrona, but also other authoritative support. At times, the hagiographical creation and initiative of a single individual, someone possessing the skill to produce written texts and access to the publishing industry, stands behind a canonization project. Orthodox local history specialists and journalists working in the provincial media, both professionals and amateurs, fill this role. Incidentally, this happens not only in the provinces: the first book that collected the stories of several contemporary female el- 
ders, Holy Women of the Russian Land, ${ }^{5}$ was written by a female staff member of the Moscow journal Literary Studies and published by this journal's press (Il'inskaia 1994), while Gennady Durasov, the author of essays on the female elder Schema-nun Makaria and the energetic popularizer of her veneration, began as a specialist in the folk culture of Northern Russia and formerly wrote essays on the clay toys of Kargopol, village chastushki [four-line verse ditties that can have lyric, topical, bawdy, or humorous content - Translator], and the like, essays that were entirely academic, though not devoid of patriotic sentimentality. ${ }^{6}$

Is it possible that contemporary saints originated exclusively from the creative imagination of the authors of hagiographical literature? In general, we are inclined to answer this question in the affirmative. But this particular answer requires very important qualifications that may fundamentally alter our stance toward the origin of the practices and texts that constitute the living fabric of the veneration of new saints. And here one must keep in mind that in discussing these stories we still must distinguish between two planes - praxis and narrative - if only analytically, that is, conditionally, since it must be clear to the impartial reader that stories about a saint, their composition, transmission, and the reading of and listening to them also constitute religious practices, together with devotional prayers, pilgrimages, and the singing of akathists.

As far as praxis is concerned, the author of a saint's life relies to a certain degree on extra-textual, empirical, factual information, direct-

5. The word translated here as "women," matushki, is the plural of a form of the word "mother (matushka instead of the usual mat') that shows affection and respect, and can also refer to an Orthodox priest's wife, a nun, or an elderly woman - Translator.

6. Hagiographical texts concerning the spiritual mother Makaria have been published many times. See, for example, Durasov 1994.

7. A hagiographical composition, a book, can become not only an informational but also a material mediator between a saint and a potential devotee. Note the introduction to the description of a posthumous miracle by one of the new blessed female elders, Schema-nun Maria (Matukasova, also known as Maria of Samara): "Somehow in church I found out about the blessed Schema-nun Maria Ivanovna Matukasova and ordered a book about her by mail. I received the book on January 29, 2002. When I opened the package and caught sight of the portrait of the Great Elder, tears flowed from my eyes. Tears and great agitation also accompanied my reading of the book. I wanted to get through the book quickly, and at the same time I didn't want the book to end. In short, everything I learned made a very strong impression on me, and I went to church.” And when the writer of the letter, Olga Medzhidova, from the town of Buguruslan (although the choice of certain turns of phrase and the general stylistics of the letter make one suspect that the Samara journalist Anton E. Zhogolev [Zhogolev 2006], the author of articles and a book about Mother Maria, had something to do with the composition of this text), began to tell her acquaintance about her experiences with the book, she saw, "beyond the church, in the east, against the background of a solid gray canvas a golden radiance like a crown" (Sviatye matushki 2010, 179-80). 
ly linked to the cult being portrayed. In other words, behind the saint's story and in the story itself there always lies the factual background, which in principle the reader can verify - the venerated holy sites associated with the life and death of the hagiography's protagonist (first and foremost the saint's burial place); other people who were witnesses of the saint's great deeds or at least their recollections of these deeds; and, when possible, other documents (photographs and so forth). Of course, we realize that all of these things can be used by the author of a hagiography as he or she wishes, but, nonetheless, basic common sense and knowledge of the general conventions of presenting information place natural limits on the author's creative freedom.

The hagiographical literary tradition may serve as a still more significant system of limitations and guidelines shaping a hagiographical narrative. This tradition is grounded in the existing canon and simultaneously strives to conform to the expectations and discursive customs of the audience, elements that change with the times. In other words, the text of a saint's life must be recognized by its readers as hagiographical, while its main hero or heroine must look and act in this tale as a saint should. In practice, though, the world of the hagiographical canon proves to be not quite so conservative: the clichés and features common to other writings in the canon leave sufficient room for individual authorial creativity, as well as for the development of old images through the acquisition of new meanings as these images enter a changing historical context. The lives of blessed female elders present an extremely telling example of the functioning of these mechanisms. Below we shall describe how long-standing narrative patterns are realized in these hagiographies and how new ones arise.

As already noted, there is every reason to speak of a new type of Orthodox sainthood established over the course of the last century and a half - that of the blessed female elders. ${ }^{8}$ These women possess two special qualities, the gifts of "spiritual discernment and insight," and accordingly fill two roles, as spiritual advisor and as counselor-helper in the difficult matters of everyday life. One can gain an understanding of the elders' first function through an example from the hagiography of the female elder Schema-nun Serafima of Michurinsk. One of the elder's female devotees tells a story about her friend, who wanted to go with her

8. The comparison of the image of the female elder with that of the male elder is complex and merits a separate discussion. For some observations on this topic, see Kormina 2013.

9. A quite concise record of the spiritual feats of blessed female elders can be found in the life story of Maria of Staraia Russa (see Sviatye matushki 2010: 379). 
to the dear mother [matushka] and was always asking her: "When will you take me with you?" I asked the mother's approval to bring her along, but she objected: "No, I am already [too] old to receive people." Having returned, I told my sister about all this, and she burst into tears: "What's to become of me? Shall I perish? For no matter how much I go to church, I never see the elders." (Sviatye matushki 2010, 253)

The story's protagonist links the question of her eternal soul's posthumous fate directly to the presence of a spiritual advisor - in this case she sees her friend (her "sister") in this role of spiritual patroness and, we may add, attains what she desired: "and Maria became the holy mother's [spiritual] child" (Sviatye matushki 2010, 254). The reputation of the blessed female elder depends to a much greater degree, however, on how she fulfills her second function, that of helper and counselor, to whom various people, not necessarily her "spiritual children," turn in difficult situations of life. This is how the documentary film One Favored by the Queen of Heaven describes this aspect of the activity of one of the currently most well-known female elders:

And all these people kept coming and coming to Temkino. Cast aside by the indifference of official medicine, they awaited deliverance from the infirmities oppressing them through the prayers of the blessed female elder. And she received everyone, teaching them to support her prayer with their own. "Say the Our Father and the Hail Mary," she said. "Go to confession and take communion, and then you will be healed." She herself prayed for forgiveness for their sins and took upon herself all their spiritual and bodily afflictions. Only the special grace of God helped Schema-nun Makaria to bear this immeasurable burden. (Khoroshavina 2009)

Incidentally, the idea that the elder takes upon herself the problems of others, their cares and sins, and bears them in her suffering, is one of the typical features of such stories.

\section{"She is already dead to the world"}

Nevertheless, these roles, presented in detail and repeatedly in the hagiographies of female elders, still do not make these women a special category of saints. The portrait of a typical female elder necessarily contains a sign of special distinction that in secular language would be called a disease, either mental or corporal. In cases of insanity, even if feigned, the situation is more or less clear: in this the 
blessed female elders follow the traditions of the fools for Christ. The sole canonized female holy fool in the Russian Orthodox Church, St. Ksenia the Blessed of Petersburg, who lived in the eighteenth century, appears to be paired in the information space of the contemporary veneration of saints with the recently canonized and relatively recently deceased Matrona of Moscow, whom they also called blessed ["blessed" (blazhennaia) can also have the meaning of "a holy fool" Translator]. Their hagiographies are often published as a single book, paired companion icons are produced, and beyond the borders of the church world proper, the two women are known as patronesses of the two capital cities, as fellow countrywomen, friends, and, to a certain extent, rivals. The enigmatic way of speaking of holy fools, the inclination to unusual actions, the meaning of which is discovered only after the passage of time - these traits, albeit significantly reinvented, are nonetheless the recognizable legacy of the hagiographical canon of saints who were holy fools (Ivanov 2005).

The innovation in hagiographical writings about the new female elders consists of the marked corporeality of the images of these saints. First, speaking in contemporary terms, many, if not the majority, of these elders were people with special needs or simply invalids. This attracts the reader's attention initially to the state of the elders' bodies and creates a particular frame for the reception of the hagiographical narrative. A second striking trait characterizing the hagiographical portraits of the blessed elders is the presence of certain physical attributes, particularly a special, unmistakable fragrance, making the material dimension of their image still more powerful. On the one hand, all this is doubtlessly connected with the general tendency of contemporary hagiography to portray saints to their existing and potential devotees as personages intimate with cultural and material space. On the other hand, this powerful corporeality of the saint, which may evoke positive emotions in the reader, heralds the material mark of sainthood, something Robert Orsi, after Peter Brown, calls presence (Orsi 2008, 12-16). A person can hear or sense the warmth and fragrance of grace and in doing so can experience unmediated contact with the transcendent. Usually, such contact is thought possible only through mystical experience, accessible to select "religious virtuosi." But in the new hagiography an elite mystical experience gives way to the functioning of the organs of the senses, an activity common to any human being.

Upon opening one of the compendia devoted to contemporary holy women, one would find that nearly all of them suffered from various serious infirmities that were either congenital or acquired at an ear- 
ly age. Matrona of Moscow was born blind, entirely without eyes, and another Matrona (of Anemniasevo) became blind at the age of seven after contracting smallpox. Schema-nun Makaria (Artem'eva) lost the use of her legs in early childhood and spent most of her life seated or lying in bed. The Blessed Liubushka of Riazan "remained in a state of enervation" from the age of fifteen, that is, she was paralyzed. We could continue this list, adding new names, but the diagnoses would remain basically the same - paralysis and blindness.

To be sure, pain and physical suffering are not something unusual and surprising in the Christian's experience: the sufferings of Christ and the torments of the martyrs fill (and even define) this experience, finding reflection not only in saints' life stories, but also in iconography, in which the saints are depicted with the instruments of torture or the parts of their bodies that have suffered, such as St. Paraskeva with her own eyes on a platter in her hands. Stigmata and extreme forms of asceticism - the nakedness of fools for Christ and the hunger of the hermits - are also portrayed. One cannot say that "old" saints did not suffer - they suffered, and some obtained the salvation of their souls through this. For example, one of the Kiev-Pechersk fathers, Pimen the Much-Ailing, a hero of the Old Russian paterikon, well-known solely for his humility in the face of severe illnesses, said: "I would rather turn into a corpse in this life, so that in the next life my body will be incorruptible; I would rather endure stench here, so as to delight in ineffable fragrance there" (Dimitrii Rostovskii [Dimitry of Rostov] 1999, 85).

Christian literature explores the phenomenon of illness not only through hagiographical narrative but also through theological reflection. The theodicy of bodily ailments arises in answer to the question: Why does God send illnesses to a person? Church and Church-related literature gives a simple and persuasive answer to this question - for punishment and correction. But why does God send sickness to those who are already pious and seem not to deserve punishment? Generally speaking, the correct answer to this question is known from God's dialogue with Job: "You want to overturn my judgment, to accuse me, in order to justify yourself?" (Job 40:3), ${ }^{10}$ that is to say, "You are sure you have the right to question me about the reason for your sufferings?" Incidentally, answers formulated in a somewhat different mode possess great practical value: afflictions are sent to a pious Christian to

10. The above is a translation of the Russian biblical text. This verse in an English-language version of the Bible, such as the New Revised Standard Version, is numbered as Job 40:8 and reads in the NRSV as follows: "Will you even put me in the wrong? Will you condemn me that you may be justified?” - Translator. 
test the believer's faith and purify the soul, ${ }^{11}$ that is, the believer shares the fate of Job the Long-Suffering. Or again another variant is possible, without in practice excluding the first: a terrible affliction is sent to a person so that through the future recovery of the patient the glory of God is revealed to the world. (On this see Ob iskusheniiakh 1994.) Thus, Pimen the Much-Ailing also recovers before death in a miraculous way, in order to take communion, to show the brothers his resting place, and to pass away right there, that is to cross over where "there is neither sickness, nor sorrow, nor sighing, but life everlasting."

In the case of the blessed female elders, however, their ailments do not presuppose healing and do not aid in spiritual growth. In this instance physical infirmities document, so to speak, these women's special status as living saints. To have a serious illness and to suffer from it already serves as convincing proof of sainthood. The disease is not a trial from which one may emerge with merit; it is a clear sign that a person who has not yet experienced death belongs to the heavenly world. ${ }^{12}$

Let us see how this plays out on the level of the narrative's internal logic. The description of the first miracle in the hagiography of Matrona of Anemniasevo is constructed in the following way; one of her fellow-villagers turned to the blind and paralyzed Matrona for help, commenting upon his decision thus:

"Matresha, now [since] you have already been lying here several years, you are no doubt pleasing to God. My back hurts, and I can't saw [wood]. Touch my back, maybe, and something will pass from you [to me]. What am I to do? I've had treatments; the doctors don't help." Matrona did as he asked, and the pain in his back indeed ceased. (Sviatye matushki 2010, 370)

In another saint's life the authors of the narrative directly correlate the malady that unexpectedly befell the saint with the wonder-working abilities that appeared within her:

11. And one can find grounds for this assertion in Scripture: "Since therefore Christ suffered in the flesh, arm yourselves also with the same intention (for whoever has suffered in the flesh has finished with sin), so as to live for the rest of your earthly life no longer by human desires but by the will of God" (1 Peter 4:1-2, NRSV). [The Russian biblical text begins with "Since Christ suffered for us (za nas) in the flesh ...." - Translator.]

12. In his book, the priest Alexander Shantaev proposes a completely different approach to understanding the physical impairment of blessed female elders. He explains the veneration of new, handicapped saints as "the great exhaustion of the nation, which has broken itself in its debilitating conquest of the summit." If one takes into account the rather long history of this practice of veneration, his view leaves the reader with an important question: Just when did this bold assault on the heights begin? (See Shantaev 2004, 70). 
Once, an old woman came to her home. Looking at Feodosia, she said with surprise: "How little she is, and she's already walking." And then she patted her on the back. Right then the little girl's knees buckled and she fell down. Something was wrong with Feodosia's legs, and, according to the holy mother, "from the age of three she did not walk a step." Thus began the many years of trial that fell to her lot. But at the same time a gift was given to her, which great Christian zealots have received through long, persistent spiritual effort, the gift of healing and saving. (Shevchenko 2004)

In other words, what came to others through great Christian deeds came to little Feodosia (the future Schema-nun Makaria) with her affliction.

A still clearer sign that a blessed female elder was preordained for sainthood is her blindness. ${ }^{13}$ The inability to see this world permits one to gain a glimpse of another world inaccessible to a typical sighted person, a glimpse "of another spiritual dimension, in which the dead associate with the living, in which the inner eyes see what is hidden from human eyes" (Sviatye matushki 2010, 380). And, alternatively, in the hagiographer's imagination blindness is correlated with the idea of holy ignorance:

The holy mother [matushka] [. . .] became blind at the age of six. [. . .] She lived for seventy years in child-like innocence, not seeing the filth of the surrounding world. [. . .] For this innocence the Lord bestowed exceptional insight on the mother, which astounded all who came to her. (Sviatye matushki 2010, 382-83)

People who spend their whole life lying in bed or not seeing the wide world are involuntarily associated with the world of death and evoke not only pity but also horror. In fact, a little line in the portrait of the blind female elder Poliushka of Riazan arouses exactly these feelings in the reader: "She was small in height, very plump, with a little kerchief on her head, and eyes with no pupils" (Evsin 2001). Is this not similar to a still from the film The Walking Dead? And when one re-

13. It should be noted that the correlation between sainthood and blindness in hagiographical narratives represents quite a new phenomenon, explained by the following circumstance: although in world culture the image of the blind seer has been widely disseminated, in Eastern Christian hagiography before this point there had not been blind saints or their sainthood was not linked to this attribute. In fact, the Christian discursive tradition draws a very close connection between the concepts of blindness and unbelief, error, and atheism (Matthew 15:14, Luke 6:39, John 9:39-41), which until relatively recent times "blocked" the appearance of hagiographical images such as these. 
calls that only someone who has died can become a saint in the fullest sense, it will not be surprising that hagiographers readily, although perhaps not always consciously, resort to "the code of death" in order to signify the special status of their protagonists as living saints.

It is entirely to be expected that the classic theory of Victor Turner should come to mind at this point, according to which the status of an individual temporarily excluded from the system of normal social relations is represented through the symbols of death - dying and resurrection (Turner 2011). In other words, a person existing in a liminal state is endowed with the qualities of the deceased: "liminality is frequently likened to death, to being in the womb, to invisibility, to darkness, to bisexuality, to the wilderness, and to an eclipse of the sun or moon" (Turner 2011, 169). And while the paradigmatic youths from aboriginal tribes experience this situation during initiation rites as temporary and linked to the transition to a new social phase, for certain social groups or roles liminality is permanent.

The semiotic dimension of death always has distinct cultural, morphological, and functional characteristics, and as we have seen in the case of our living saints this dimension is usually symbolized through a lack of vision and mobility. We have already had to write of blindness and ailments connected to impaired motor skills as telling signs of their possessors' belonging to the world of death (Shtyrkov 2012; on blindness see pp. 137-41; on motor function disabilities see pp. 64-66). According to folk tales of the miraculous punishments of blasphemers, those who chop up icons or throw bells down from a parish church's bell tower are inevitably brought low by paralysis. The morally depraved who attack a saint or a shrine are punished with blindness: Saul, a persecutor of Christians who was struck blind, serves as an archetypal example of this; he obtained his sight again after repenting, accepting Holy Baptism, and taking a new name. Thus, in the Orthodox narrative tradition these symbols are familiar and easily understandable, although depending on the context they may be used with opposite meanings. To be sure, in the context of contemporary hagiographical writings the use of this semantic code seems rather archaic, folkloric, or, to use the expression of the well-known religious publicist Fr. Andrei Kuraev, "too human" to someone accustomed to traditional hagiographical literature. This is not only a matter of the signs of liminality through which the image of the living saint comes to light, but also of the special "corporeality," the material tangibility of the saint's holiness, the description of which gives a distinctive coloration to hagiographical stories of the "blessed female elders." 


\section{"Your old man reeks"}

The olfactory code of sainthood is traditional in hagiographical literature. Saints' lives repeatedly point to a special unearthly fragrance that comes from relics and especially from saints who have just passed away. A breakdown in this topos results in the unbalancing of the whole hagiological system (something that F. M. Dostoevsky employed in The Brothers Karamazov, having his protagonists react bitterly to the appearance of the smell of corruption from the body of a deceased man of God). (For an interpretation of this episode, see Bogdanov 2010, 121-26.)

Blessed female elders are the kind of saints that give off a smell while living. A strong, heavy odor serves as a kind of "footprint of the holy fool" in the hagiography of contemporary female elders (recall Old Russian holy fools' custom of sleeping in manure). One female forerunner of these elders, who lived in the early nineteenth century in the Serpukhovsky Vladychny monastery, a former lady-in-waiting, the "fool Evfrosinia,"

never cleaned [. . .] her wretched cell. [. . .] The floor was littered with the remains of food for the animals that fed out of a special trough that stood on the floor right there in the cell. [. . .] The air in the cell was terribly oppressive. It was difficult for an ordinary person to breathe in this room. (Bezumiem mnimym 2005, 214-15)

In answer to a question from a female visitor about the ghastly air and the animals in her living quarters the blessed woman replied: "For me this replaces the perfume I used to use so much at court" (Bezumiem mnimym 2005, 215). In contrast to the female elders of the twentieth century Evfrosinia did not have bodily defects; she was able to move herself and consciously made a decision about the cleanliness of her quarters - this was one of her spiritual feats as a holy fool. The odors in her "cell" speak of the holy fool's intentional infringement of the rules and of the blurring of the border between the clean and the unclean, in this case - between the human and the animal, the home and the barnyard.

On the whole, direct mentions of female elders giving off a smell while alive are quite rare; the sole instance known to us is that of the blessed Natalia, who smelled of goats (Belov 2011, 59). But even for a reader not possessing a powerful imagination it is not difficult to imagine the odors that filled the living quarters of Evdokia of Diveevo, for 
example, who "for many years lay on a bed among uneaten scraps and matted rags. The bread had gone green, heaps of crackers mounted up on the bed, where cockroach antennae and mouse tails flitted about" (Il'inskaia 1994, 116). Naturally, all of this did not keep the saint from burning with love for the Lord and for the visitors who sought a meeting with her. Curiously, St. Serafim of Vyritsa prophesied the coming of the blessed Natalia, according to her hagiography: "When Serafim of Vyritsa was going to be with the Lord [. . . ] he said: After me there will be a woman, who will give off a smell" (Belov 2011, 59), as if he were passing on the mantle of eldership to a new generation, to someone having a smell (according to accounts of his life, he himself did not give off strong odors).

But, of course, the "chief" aroma of a female elder arises after her departure into eternal life, when instead of the natural smell of death her flesh and even her possessions begin to emit a fragrance, as happens in the Orthodox world with relics and especially with wonderworking icons.

"And do you know, Valentin Nikolaevich" - wrote one of the devotees of the blessed Natalia (who in life smelled of goats) to the author of her hagiography - "that the mother's jacket, which remained with us from her, gave off fragrance during prayer? And especially when you pray not alone but with someone. We place candles, light the icon lamps, pray, and right away the jacket begins to give off a fragrance, meaning that Natalia Mikhailovna is here and hears our prayers.” (Belov 2011, 45)

By extension, fragrance also arises from photographs of female elders, from oil blessed at their graves, and the like. ${ }^{14}$ This fragrance (sometimes thought to be the scent of roses, for example) provides indisputable proof of the sainthood of the departed. One can cast doubt on the stories of a person's Christian spiritual feats, but how can one argue with a scent?

The posthumous fragrance of a female elder serves as a logical part of the narrative that while having unmistakable signs of death during her life, conversely after death she preserves - or even ac-

14. "The flow of myrrh from photographs of the Mother [Matushka] began almost at once after her righteous passing. In Diveevo in Vera Lapkova's home a photo of Maria Ivanovna emitted myrrh and fragrance in the spring of 2000. [. . .] The nun Elisaveta from Samara has a modest little album with photographs of the Mother that to this day is wondrously fragrant. [. . .] The nun Evgenia has intensely fragrant oil, blessed at the female Elder's grave, and things that belonged to her" (Sviatye matushki 2010, 185). 
quires - marks of eternal life. Truly, it is as if living saints refuse to die. Their hagiographies convey the absence of physiological indications of death: "Despite the warm season, the deceased lay in the coffin as if alive: there were no noticeable signs of decay, and a fragrance arose from the coffin; the devoutly peaceful face of the zealous woman of faith reflected heavenly bliss" (Il'inskaia 1994, 30). One can sense the presence of these saints not only through the aroma of grace; female elders invite their devotees and spiritual children to come to them at their graves and confide to them their troubles, to speak with them as if they were alive. Matrona of Moscow instructed her followers to come to her in the Danilovsky cemetery in Moscow:

If something happens to you, come to my little grave, bend down, ask for what you need - I shall give you my advice. And always go to the cemetery, when you have any need or anything. Ask with your soul, and I shall help. As I used to receive people, so I will also continue to receive them. Talk with me, tell me all your troubles, I shall see and hear you; what I say to your soul, do. (Il'inskaia 1994, 149)

\section{Conclusion}

The saturation of a hagiographical text with indications of the corporeality of the saint, the heightened naturalism of hagiographical images, has at least two sources. The first is readily apparent - Russian Orthodox literature has evolved in company with secular literature, in which naturalism of description became an important artistic technique. Everyone remembers that Alyosha Karamazov began his difficult path of doubt and seeking in response to the odor of decay from the body of his deceased spiritual mentor, the elder Zosima. However one interprets this episode, it is evident that the smell of a dead body in the cell of the recently deceased revered elder was unseemly not only in itself, but also - to Dostoevsky this was important to emphasize - as a basis for judgments about the righteousness or unrighteousness of the deceased.

The second source is linked to the logic of the hagiographical genre's development over the last century and a half, that is, the attempt to create images of widespread popular piety rooted in the national soil, and, correspondingly, images of popular saints. Hence the numerous attempts to find (or create) and legitimize a "popular" version of Orthodox spiritual heroism. Note the popular incident in the 
hagiography of Matrona of Moscow, when the righteous St. John of Kronstadt saw a very young little Matrona in the crowd of worshippers and pointed to her as to his successor. A film about Matrona gives the following commentary on this story:

New times were at hand. The holy and righteous John of Kronstadt warned repeatedly about coming upheaval. [ . . . It may be that at that moment in church it was revealed to the great pastor that Russia would need not spiritual giants but those who were simple, pure souls, like little Matrona. In the twentieth century they would be Russia's spiritual support. (Shevchenko 2006)

At a certain point, however, what became important was the image of popular saints who were appealing not only to their creators but also to the audience for popular hagiographic works. To achieve this aim, an especially urgent one in the context of Orthodox communities' existence in the hostile, atheistic environment of the Soviet state, it was necessary to democratize the narrative genre, to fill it with images, themes, and indications of the extra-textual realities of religious life that were if not familiar, then at least understandable, to the "people." In this way images of new saints have been established as pious women of God of common birth, using dialectical forms in their speech, typically discussing the scheming of sorcerers, and helping people in the situations of daily life. In addition, at times the authors of saints' lives have become so carried away that they have created literary icons of saints that not only do not fit the established hagiology and contain implicit criticism of the ecclesiastical elite and of canonical forms of Orthodox custom, but also simply seem bizarre to learned representatives of the Church's intellectual elite.

At times these dissonances have been so egregious that the authors of saints' lives have had to introduce significant revisions into the image of a saint. For example, the portraits of Matrona of Moscow and Pelagia of Riazan were substantially changed to adhere more closely to a well-defined standard. This standard involves fidelity to the fundamental forms of church discipline celebrated in the hagiographies of the righteous and adherence to fixed social position. ${ }^{15}$ Accordingly,

15. The spread of materials about the life and utterances of Pelagia of Riazan, which are replete with "folkloric" and anticlerical images and themes, became a serious obstacle to the popularization and official recognition of her cult. For more on this, see Sibireva 2006, 163-65; Kormina 2010, 9-10. For an attempt to "rehabilitate" the female elder Pelagia one may consult the already-cited booklet by Igor Evsin and his more re- 
later (and official) versions of the life of St. Matrona of Moscow emphasize the "canonicity" of her activity and her lack of pretensions to roles inaccesible to her because of her position: "The holy mother did not preach, did not teach" (this assertion, by the way, does not correspond to many incidents included in this very text). "Matrona warned her followers not to run from confessor to confessor in search of 'elders' or 'seers," and finally, "On the whole, there is nothing in Matrona's exhortations that would contravene the teaching of the holy fathers" (Sviatye matushki 135-36). Obviously, these assertions look like attempts to justify and defend the writers' saint from severe allegations by Church "authorities."

Successive attempts to produce literary icons of the new saints have resulted in these saints coming to resemble simple mortals. Hagiographers, deciding to violate the genre's conventions, permit their protagonists to be ordinary people at times. And so Matrona, who according to a legend rejected by her canonizers was not afraid even of all-powerful Stalin, feared death. This fear and her down-to-earth, non-hagiographical restlessness when awaiting the end of her earthly journey make Matrona not a shining light of the coming eternal bliss of the righteous but a mere mortal (though, to be sure, one who bore the signs of belonging to the world of the dead her entire life). For some reason she experienced childlike agitation before the most important event in life. It is therefore possible that her last words could easily be included in a children's book without fear that they might frighten a young Orthodox reader.

Dear Matrona feared death, just as all people do. Anxious, she asked the priest who came to give her communion whether her hands were folded in the right way. The priest was sincerely surprised:

- Really, mother, do you find it terrible to die?

- Terrible - the blessed elder answered meekly. (Mikhailova 2013, 18)

For its part, this carefully constructed simplicity produces an image of a popular saint who conveys an experience of Orthodoxy as a religion rooted in national tradition, simple, and understandable to all.

cent work (Evsin 2012). The well-known Moscow priest, Archpriest Artemy Vladimirov, served as the editor and authored the foreword to this edition. In a special interview with the publisher Zerna, Evsin presented the arguments and rhetoric of the champions for the reclamation of Poliushka's reputation, accusing the author of the "false hagiography" of "spiritual deception" or mental deficiency (Nikol'skii 2012). 


\section{References}

Belov, Valentin N. 2011. Gospodi, ia pravil'no govoriu? [God, do I speak properly?]. St. Petersburg.

Bezumiem mnimym bezumie mira oblichivshie: Blazhennye staritsy nashego vremeni $(X I X-X X v v$.) [Exposing the world's foolishness through holy foolishness: Blessed female elders of our times (nineteenth to twentieth centuries)]. 2005. Moscow: Russkii khronograf.

Bogdanov, Konstantin A. 2010. “'Tletvornyi dukh' v russkoi literature XIX veka: (Anti) estetika kak moral' [The putrid smell in Russian literature of the nineteenth century: (Anti) aesthetics as morality]." In Aromaty i zapakhi $v$ kul'ture [Aromas and smells in culture], compiled by O. B. Vanshtein, 2:101-33. 2nd rev. ed. Moscow: Novoe literaturnoe obozrenie.

Brown, Peter. 1981. The Cult of the Saints: Its Rise and Function in Latin Christianity. Chicago: University of Chicago Press.

Cunningham, Lawrence S. 2005. A Brief History of Saints. Oxford: Blackwell Publishing.

Dimitrii Rostovskii [Dimitry of Rostov]. 1999. Zhitiia sviatykh [Lives of the saints]. Vol. 13: August. Moscow: TERRA-Knizhnyi klub.

Durasov, Gennadii P. 1994. Bogom dannaia: Zhizneopisanie blazhennoi staritsy skhimonakhini Makarii [Given by God: The life of the blessed elder Schema-nun Makaria]. St. Petersburg: Satis".

Evsin, Igor' V. 2001. Svetil'nik very: Zhizneopisanie blazhennoi Pelagei Zakharovskoi [The light of faith: The life of Blessed Pelageia of Riazan']. Moscow: Zerna.

Evsin, Igor' V. 2012. Poliushka Riazanskaia: Povest' o slepoi pravednitse Pelagee Zakharovskoi [Poliushka of Riazan': The story of the blind woman of God, Pelageia of Riazan']. Moscow: Izdatel'skoe otdelenie khrama Vsekh Sviatykh v Krasnom Sele.

Il'inskaia, Anna V. 1994. Matushki zemli russkoi: Dukhovnye ocherki o pravoslavnykh podvizhnitsakh veka sego [Holy women of the Russian land: Spiritual essays on Orthodox ascetics of our time]. Moscow: Literaturnaia ucheba.

Ivanov, Sergei A. 2005. Blazhennye pokhaby: Kul'turnaia istoriia iurodstva [Blessed obscenities: A cultural history of fools-for-Christ]. Moscow: Iazyki slavianskikh kul'tur.

Khoroshavina, Klavdiia, director. 2009. Izbrannitsa Tsaritsy Nebesnoi: Dokumental'nyi fil'm o velikoi podvizhnitse nashego vremeni skhimonakhine Makarii (Artemevoi, 1926-1933 gg.) [One Favored by the Queen of Heaven: Documentary film on a great spiritual heroine of our time, Schema-nun Makaria (Artem'eva, 1926-1933)]. MOST-TV.

Kormina, Jeanne V. [Zhanna V. Kormina]. 2013. "Canonizing Soviet Pasts in Contemporary Russia: The Case of Saint Matrona of Moscow.” In A Companion to Anthropology of Religion, edited by M. Lambek and J. Boddy, 409-24. Oxford: Blackwell Publishing.

Kormina, Zhanna V. 2010. "Politicheskie personazhi v sovremennoi agiografii: Kak Matrona Stalina blagoslovliala [Political personages in contemporary hagiography: How St. Matrona gave her blessing to Iosif Stalin].” Antropologicheskii forum [Anthropological forum], no. 12: 1-28.

Kormina, Zhanna V., and Sergei A. Shtyrkov. 2008. "Pis'ma veruiushchikh kak reklama: 'Vsenarodnaia priemnaia' sv. Ksenii Peterburgskoi” [Believers' letters as advertising: St. Xenia of Petersburg's 'National Reception Center']. Antropologicheskii forum, no. 9: $154-84$. 
Matronushka: Akafist sviatoi Matrone Moskovskoi; Zhitie [Matronushka: Akathist to St. Matrona of Moscow; A life]. 2009. Moscow: Loza.

Mikhailova, Natal'ia, comp. 2013. Bozhii svet $v$ slepykh ochakh: Zhitie blazhennoi Matrony Moskovskoi dlia detei [The light of God in blind eyes: The life of Blessed Matrona of Moscow for children]. Moscow: Prikhod khrama Sviatago Dukha soshestviia.

Nikol'skii, Vladimir. 2012. “Pelageia Zakharovskaia i ee pochitateli [Pelageia of Riazan' and her devotees]." Pravoslavnyi internet-magazin "Zerna" [Orthodox internet-magazine Zerna], June 27. http://www.zyorna.ru/news/CX/27.06.2012.

Ob iskusheniiakh, skorbiakh, bolezniakh i uteshenie $v$ nikh: Sobrano iz tvorenii Sviatykh Ottsov i podvizhnikov blagochestiia [On trials, sorrows, and illnesses and how to seek consolation in them: Collected from the works of the Apostolic Fathers and zealots of the faith]. 1994. Moscow: Palomnik.

Orsi, Robert A. 2008. "Abundant History: Marian Apparitions as Alternative Modernity." Historically Speaking 9 (7): 12-16.

Semenenko-Basin, Il'ia V. 2010. Sviatost'v russkoi pravoslavnoi kul'ture XX veka: Istoriia personifikatsii [Sainthood in Russian Orthodox culture in the twentieth century: A history of personification]. Moscow: Izdatel'skii tsentr Rossiiskogo Gosudarstvennogo Gumanitarnogo Universiteta.

Shantaev, Father Aleksandr. 2004. Sviatye blazhennye-kaleki v sovremennoi zhitiinoi literature: Rassmotrenie osnounykh tipologicheskikh priznakov [Holy fools and disabled saints in contemporary hagiography: An analysis of their basic typological features]. Moscow: Blago.

Shevchenko, Nelli, director. 2004. Bogom dannaia: Skhimonakhinia Makariia [Given by God: Schema-nun Makaria]. Studiia ALS pro video.

Shevchenko, Nelli, director. 2006. Blazhennaia Matrona Moskovskaia: Vos'moi stolp Rossii, iz tsikla Sviatye zemli Russkoi [Blessed Matrona of Moscow: The eighth pillar of Russia, from the cycle Saints of the Russian land]. "Kapel'meister" Blagotvoritel'nyi fond V. P. Kharchenko ["Kapel'meister" - The V. P. Kharchenko Philanthropic Fund).

Shtyrkov, Sergei A. 2012. Predaniia ob inozemnon nashestvii: Krest’ianskii narrativ i mifologiia landshafta (na materialakh severo-vostochnoi Novgorodchiny) [Historical legends about foreign invasions: Folk narratives and the mythology of landscape (based on materials of the northeast Novgorod region)]. St. Petersburg: Nauka.

Sibireva, Ol'ga. 2006. "Sovremennyi sviashchennik i 'narodnoe pravoslavie' [The contemporary Orthodox priest and popular Orthodoxy].” In Religioznye praktiki v sovremennoi Rossii [Religious practices in contemporary Russia], edited by K. Russele [K. Rousselet] and A. Agadzhanian [A. Agadjanian], 148-77. Moscow: Novoe izdatel'stvo.

Sviatye matushki i podvizhnitsy zemli Russkoi $v$ XX veke prosiiavshie [Women saints and heroines of the faith shining forth in the Russian land in the twentieth century]. 2010. Nikolaev: "Litopis."

Turner, Victor W. 2011. The Ritual Process: Structure and Anti-Structure. New Brunswick, NJ: AldineTransaction.

Zhogolev, Anton E. 2006. Blazhennaia skhimonakhina Mariia [Blessed Schema-nun Maria]. Riazan: Zerna. 